\title{
Nutrient intake and digestibility of West African dwarf goats fed graded levels of Afzelia africana and Newbouldia laevis as supplements to Panicum maximum ${ }^{1}$ Ikihimioya, I., ${ }^{*}$ Okoruwa, M. I. and ${ }^{2}$ Ikhatua, U. I. \\ ${ }^{\text {I}}$ Department of Animal Science, Ambrose Alli University, P.M.B. 14, Ekpoma, Edo State, Nigeria. \\ ${ }^{2}$ Department of Animal Science, University of Benin, Benin City, Nigeria. \\ Corresponding author: *odionokos@yahoo.com; okosmich@gmail.com \\ Abstract
}

The study was conducted to determine nutrient intake and digestibility of West African dwarf goats fed graded levels of Afzelia africana and Newbouldia laevis as supplements to Panicum maximum. Twenty female West African dwarf goats aged between 5 and 7 months old with mean live weight of $6.62 \pm 0.41 \mathrm{~kg}$ were allotted to five dietary treatments with two replicates of two goats per treatment in a completely randomised design. The compared diets were: $T_{A}$ (100\% Panicum maximum), $T_{B}\left(25 \%\right.$ Afzelia africana and $75 \%$ Panicum maximum), $T_{C}(50 \%$ Afzelia africana and $50 \%$ Panicum maximum), $T_{D}(25 \%$ Newbouldia laevis and $75 \%$ Panicum maximum) and $T_{E}(50 \%$ Newbouldia laevis and $50 \%$ Panicum maximum). A metabolism trial was conducted at the end of the feeding trial to assess the diets on nutrient digestibility after the nutrient intake study of the goats. Results obtained showed that total hemicelluloses intake $\left(62.48\right.$ g.day $\left.{ }^{-1}\right)$ was significantly $(p<0.05)$ higher in $T_{A}$ compared with other diets. Total crude protein intake (43.45g. $\left.d^{-1}\right)$ and hemicelluloses digestibility (92.20\%) were higher significantly $(p<0.001)$ and $(p<0.01)$ respectively in $T_{C}$. Total lignin intake $\left(36.22 g . d^{-1}\right)$ and organic matter digestibility $(77.70 \%)$ were significantly better $(p<0.05)$ and $(p<0.01)$ respectively in $T_{D}$. Digestibility of neutral and acid detergent fibre (55.71\% and $49.79 \%)$ were significantly higher $(p<0.05)$ and $(p<0.001)$ while dry matter digestibility $(83.49 \%)$ was significantly better $(p<0.01)$ in $T_{E}$ than other treatment diets. Total dry matter, organic matter, neutral detergent fibre, acid detergent fibre and cellulose intakes with digestibility of crude protein, lignin and cellulose were not significantly $(p>0.05)$ affected by treatment diets. It was concluded that the combination of Panicum maximum based diet with Newbouldia laevis in a ratio of 50:50 had the potential to enhance nutrient digestibility in goats.

Keywords: Nutrient intake, digestibility, Afzelia africana, Newbouldia laevis, goats

\section{Introduction}

The problem of low animal protein consumption in Nigeria has been channeled down to the insufficiency in livestock production in the tropics. This constraint is responsible for the existing high price of animal products which make them out of reach to the average Nigerian. One of the ways forward with this challenge is by directing efforts at promoting and encouraging ruminant livestock production. Goat production has been considered as a valuable small ruminant enterprise with the potential of meeting world's increasing demand for animal protein in less developed countries (Okunade et al., 2014). However, goat production in Nigeria suffers from serious shortage of feeds particularly during the dry season where the quantities available are limited. The quality of pasture is poor and their nutrients are not enough to cover maintenance and productive requirement of goats (Onyeonagu et al., 2011). This situation is further aggravated by overgrazing in most areas where pastures are 


\section{Nutrient intake and digestibility of West African dwarf goats}

grown with scarcity of conventional feedstuffs. Hence, goat farmers in Nigeria have faced a lot of challenges in generating income from their stock, due to slow growth rate and unstable weight gain related to seasonal imbalance of feeds (Okoruwa and Bamigboye, 2015). The dearth of adequate forage supply to meet the nutrient requirement of goats particularly during the dry season coupled with the high cost of feedstuffs have led to the search for shrubs and tree foliages which could be used as cheaper available alternative supplements to grasses (Okoruwa et al., 2016).

Afzelia africana and Newbouldia leavis are common to forest areas with high potential for the production of browse for ruminants (Ikhimioya and Imasuen, 2007). They are available all year round, contributing their succulent leaves and twigs to goat feeding and production. The use of these browse plants in goat nutrition has become an essential practice, especially in the dry season when herbaceous forage are scarce and low in quality. Fadiyimu et al. (2011) reported that the sustainable way of improving the feeding value of poor quality pasture is through supplementation with browse plants. Though their fodder value is universally acknowledged, their ranking in terms of intake and digestibility are low. Hence, there is paucity of information on the use of Afzelia and Newbouldia foliages as supplements to grasses. The objective of this study therefore, was to determine nutrient intake and digestibility of West African Dwarf goats fed graded levels of Afzelia africana and Newbouldia laevis as supplements to Panicum maximum.

\section{Materials and methods \\ Study Area}

The feeding experiment was conducted at the Small Ruminant Experimental Unit of the Teaching and Research Farm, University of Benin, Benin City, Nigeria. The area falls within latitudes $3^{\circ} 8^{\prime}$ and $7^{\circ} 8^{\prime} \mathrm{N}$ and longitudes $3^{0} 2^{\prime}$ and $9^{\circ} 8^{\prime} \mathrm{E}$. The climate is humid and is located in the interface between the tropical rainfall and derived savanna zone of southsouth Nigeria. It receives a mean annual temperature and rainfall of about $31^{\circ} \mathrm{C}$ and $1556 \mathrm{~mm}$ respectively.

Experimental diets

Panicum maximum (after 6 to 8weeks regrowth) was obtained from the pasture land within the Teaching and Research Farm. It was chopped with a sharp cutlass manually to about $5 \mathrm{~cm}$ lengths after allowing it to wilt over night. Afzelia africana and Newbouldia laevis were cut fresh daily from naturally growing stands within and around the University vicinity. They were defoliated on clean corrugated iron sheets before being measured and fed to the animals. This was to ensure that the animals received only the leaves of the test plants. The percent ratios of the test leaves of Afzelia africana (Afz) and Newbouldia laevis (Nwb) to the basal diet of Panicum maximum (PM) in the dietary treatments were 25:75 and 50:50 each. Sole intake of PM was served as the control group.

The five treatment diets that contained the following were then prepared; $\mathrm{T}_{\mathrm{A}}(100 \mathrm{PM})$, $\mathrm{T}_{\mathrm{B}}$ (25Afz : 75PM), $\mathrm{T}_{\mathrm{C}}(50 \mathrm{Afz}: 50 \mathrm{PM})$, $\mathrm{T}_{\mathrm{D}}(25 \mathrm{Nwb}: 75 \mathrm{PM})$ and $\mathrm{T}_{\mathrm{E}}(50 \mathrm{Nwb}: 75 \mathrm{PM})$.

Experimental animals, feeding and management

Twenty female West African dwarf goats procured from villages around Benin City, aged about $5-7$ months old and with body weight of between 5.50 and $9.50 \mathrm{~kg}$ were used for the study. The goats were acclimatised for 21days during which they were dipped in Diazintol solution against ecto-parasites and dewormed with Ivomec against internal parasites. Thereafter, they were vaccinated against Pestes des petit 


\section{Ikihimioya, Okoruwa and Ikhatua}

Ruminant (PPR). Subsequently, they were injected with oxytetracycline (L.A.) antibiotic and vitamin B-complex intramuscularly at the dosage of $1 \mathrm{ml} / 10 \mathrm{~kg}$ live weight of the animals to enhance their resistance to infections and stress. During the 21-day period, the goats were introduced and maintained on the test leaves and Panicum maximum as well as get them used to the confinement. After the acclimatisation, the goats were transferred to the individual experimental pens that were identified by wooden tags and previously swept clean, washed with Morigad $®$ solution to disinfect. Each pen measured $1 \times 1.5 \mathrm{~m}$ and was bedded with wood shavings with feeder and drinkers on the concrete floor. Cleaning of the pens was done weekly. The goats were randomly divided into the five dietary treatment groups of four goats per treatment in a completely randomised design. Each treatment was replicated twice with two goats and they were balanced for body weight.

Feeding of the goats was done once daily at 09:00hour for 102days aside from the initial 21days of acclimatisation. Water was provided ad libitum. The quantity of the leaves offered to each goat was calculated on the basis of $50 \mathrm{~g} \mathrm{DMkg}^{-1} \mathrm{~d}^{-1}$. The percentage ratios of the test leaves to the basal diet of Panicum maximum was used to determine the proportion of each plant leaf in the daily feed allowance offered to each goat. The weights of the feed offered and that of the leftover were used to compute each goat feed intake

\section{Nutrient digestibility study}

After the feeding trial, goats from each treatment group were moved to individual metabolism cages allowing for separate collection of faeces and urine to determine digestibility in the goats. The goats were maintained on their previous respective treatment diets with free access to water. They were allowed 7 days adjustment period before 7-day total collection of faeces as well as measurement of quantity of feed offered and residual feed. Daily feed and faecal sample collected were oven dried at $100^{\circ} \mathrm{C}$ for 5hours, cooled, weighed and bulked. About $10 \%$ of the bulked samples were taken individually and stored for chemical analysis. Thus, nutrient digestibility was calculated as:

Nutrient digestibility $=$

Nutrient intake - Nutrient in faeces X 100

$$
\text { Nutrient intake }
$$

1

\section{Chemical analysis}

Feed and faecal samples were oven dried at $100^{\circ} \mathrm{C}$ for 5 hours, cooled and weighed. The weight difference between initial weight and dried weight were taken as the moisture content in the leaves offered and faeces voided and then converted to percentage. The percentage dry matter content was therefore obtained as the difference between 100 and percentage moisture content (AOAC, 1990). They were then bulked and milled to pass through $1 \mathrm{~mm}$ screen sieve. Thereafter, the proximate composition of feed and faecal samples was determined using the procedure of AOAC (1990). Determination of neutral and acid detergent fibre with lignin was by the method of Goering and van Soest (1970). Hemicellulose was obtained from the difference between neutral detergent fibre and acid detergent fibre while the difference between acid detergent fibre and lignin accounted for cellulose content.

\section{StatisticalAnalysis}

All data generated from nutrient intake and digestibility were subjected to analysis of variance (Gomez and Gomez, 1984) while significantly different means were separated by Duncan's (1955) multiple range test within the same package 


\section{Nutrient intake and digestibility of West African dwarf goats}

\section{Results}

The chemical composition of Panicum maximum and the test tree leaves determined in this study are shown in Table 1. Average dry matter value of 35.82 $\mathrm{g} / 100 \mathrm{~g}$ in this study, ranged from 30.50 $\mathrm{g} / 100 \mathrm{~g}$ in Afzelia africana to $42.24 \mathrm{~g} / 100 \mathrm{~g}$ in Newbouldia laevis. Crude protein content ranged from a low value of 8.44 $\mathrm{g} / 100 \mathrm{~g}$ in Panicum to a high value of 29.85 $\mathrm{g} / 100 \mathrm{~g}$ in Afzelia africana. Ash values recorded the highest in Panicum (12.86 $\mathrm{g} / 100 \mathrm{~g}$ ) and lowest in Newbouldia laevis $(2.49 \mathrm{~g} / 100 \mathrm{~g})$. Crude fibre values were similar between Panicum (21.34 g/100g) and Afzelia africana $(24.24 \mathrm{~g} / 100 \mathrm{~g})$ with exception of Newbouldia laevis (12.38 $\mathrm{g} / 100 \mathrm{~g}$ ). Ether extract and nitrogen free extract that ranged from $6.46 \mathrm{~g} / 100 \mathrm{~g}$ to 13.59 $\mathrm{g} / 100 \mathrm{~g}$ and $31.31 \mathrm{~g} / 100 \mathrm{~g}$ to $55.55 \mathrm{~g} / 100 \mathrm{~g}$ respectively, were highest in Newbouldia laevis. Neutral and acid detergent fibre that ranged from $60.87 \mathrm{~g} / 100 \mathrm{~g}$ to $70.51 \mathrm{~g} / 100 \mathrm{~g}$ and $39.81 \mathrm{~g} / 100 \mathrm{~g}$ to $47.50 \mathrm{~g} / 100 \mathrm{~g}$ respectively were highest in Panicum and lowest in Newbouldia laevis. Lignin ranged between 9.97 and $15.93 \mathrm{~g} / 100 \mathrm{~g}$ while cellulose and hemicelluloses ranged from $23.88 \mathrm{~g} / 100 \mathrm{~g}$ to $37.52 \mathrm{~g} / 100 \mathrm{~g}$ and 11.06 $\mathrm{g} / 100 \mathrm{~g}$ to $23.01 \mathrm{~g} / 100 \mathrm{~g}$ respectively.

Table 1: Chemical composition (g/100g) of Panicum maximum and the test plant leaves

\begin{tabular}{lccc}
\hline Nutrient components & Panicum maximum & Afzelia africana & Newbouldia laevis \\
\hline Dry matter & 34.72 & 30.50 & 42.24 \\
Crude protein & 8.44 & 29.85 & 15.57 \\
Ash & 12.86 & 6.66 & 2.49 \\
Crude fibre & 21.34 & 24.24 & 12.38 \\
Ether extract & 6.46 & 7.95 & 13.59 \\
Nitrogen free extract & 50.90 & 31.31 & 55.98 \\
Neutral detergent fibre & 70.51 & 53.97 & 50.98 \\
Acid detergent fibre & 47.50 & 42.69 & 39.81 \\
Lignin & 9.97 & 11.94 & 15.93 \\
Cellulose & 35.52 & 30.75 & 23.88 \\
Hemicellulose & 23.01 & 11.28 & 11.06 \\
\hline
\end{tabular}

The results for nutrient intakes of West African dwarf goats fed Afzelia afircana and Newbouldia laevis in two different ratios as supplements to Panicum maximum are presented in Table 2. Dry matter intake from the test plant leaves varied significantly $(\mathrm{p}<0.001)$ between the dietary treatments ranging from 71.90 to $114.52 \mathrm{~g} /$ day. However, total intake of dry matter was not significantly different $(\mathrm{p}>0.05)$ as well as when expressed as metabolic weight. Total dry matter intake from the test diets ranged from $256.35 \mathrm{~g} /$ day $\left(T_{B}\right)$ to $306.78 \mathrm{~g} /$ day $\left(T_{D}\right)$. From each of these supplemental diets, dry matter intakes represented 4.61, 3.79, 4.10, 4.26 and 4.50 percent of their body weights for diets $\mathrm{T}_{\mathrm{A}}$,
$\mathrm{T}_{\mathrm{B}}, \mathrm{T}_{\mathrm{C}}, \mathrm{T}_{\mathrm{D}}$ and $\mathrm{T}_{\mathrm{E}}$ respectively. Organic matter intake from Afzelia africana and Newbouldia laevis (67.11 - 106.89g/day) as well as Panicum maximum (146.51 $236.60 \mathrm{~g} /$ day) were highly significant $(\mathrm{p}<0.001)$ among treatment diets. No significant differences $(p>0.05)$ were observed in total and metabolic organic matter intakes. Variations between the treatment diets in terms of total intake of crude protein were highly significant $(p<0.001)$. The recorded values ranged from $22.91 \mathrm{~g} /$ day in $\mathrm{T}_{\mathrm{A}}$ to $48.45 \mathrm{~g} /$ day in $\mathrm{T}_{\mathrm{C} \text {. Total }}$ crude protein intake was observed to be higher from the diets supplemented with Afzelia africana than those supplemented with Newbouldia laevis. Differences in 


\section{Ikihimioya, Okoruwa and Ikhatua}

intakes of neutral detergent fibre from the supplements Afzelia africana and Newbouldia laevis as well as from Panicum maximum were significant $(\mathrm{p}<0.001)$ between the trial diets. The highest total neutral detergent fibre intake although not significant $(\mathrm{p}>0.05)$ was $205.19 \mathrm{~g} /$ day from $\mathrm{T}_{\mathrm{D}}$, while the least of $164.10 \mathrm{~g} /$ day was consumed in $\mathrm{T}_{\mathrm{B}}$.

Table 2: Nutrient intake by West African Dwarf goats fed a basal diet of Panicum maximum supplemented with Afzelia africana and Newbouldia laevis

\begin{tabular}{|c|c|c|c|c|c|c|}
\hline \multirow[b]{2}{*}{ Nutrient intake } & \multicolumn{5}{|c|}{ Treatment Diets } & \multirow[b]{2}{*}{ SEM \pm} \\
\hline & $\mathbf{T}_{\mathrm{A}}$ & $\mathbf{T}_{\mathbf{B}}$ & $\mathbf{T}_{\mathrm{C}}$ & $\mathbf{T}_{\mathrm{D}}$ & $\mathbf{T}_{\mathrm{E}}$ & \\
\hline DM from Afz : Nwb & - & $71.90^{c}$ & $114.52^{\mathrm{a}}$ & $86.86^{\text {bc }}$ & $99.46^{\mathrm{ab}}$ & $10.98^{* * *}$ \\
\hline DM from PM & $271.52^{\mathrm{a}}$ & $184.45^{\mathrm{c}}$ & $169.00^{\mathrm{c}}$ & $220.01^{b}$ & $188.65^{\mathrm{c}}$ & $16.42^{* * *}$ \\
\hline Total DM intake & 271.52 & 256.35 & 283.52 & 306.87 & 288.11 & $21.88^{\mathrm{NS}}$ \\
\hline Metabolic DM intake & 68.88 & 57.27 & 62.99 & 66.56 & 68.55 & $5.12^{\mathrm{NS}}$ \\
\hline OM from Afz : Nwb & - & $67.11^{\mathrm{b}}$ & $106.39^{\mathrm{a}}$ & $84.69^{\mathrm{ab}}$ & $97.23^{\mathrm{a}}$ & $10.73^{* * *}$ \\
\hline $\mathrm{OM}$ from PM & $236.60^{\mathrm{a}}$ & $154.85^{\mathrm{c}}$ & $146.51^{\mathrm{c}}$ & $195.64^{b}$ & $164.39^{c}$ & $14.40^{* * * *}$ \\
\hline Total OM intake & 236.60 & 221.96 & 253.40 & 280.34 & 261.62 & $21.46^{\mathrm{NS}}$ \\
\hline Metabolic OM intake & 60.02 & 50.92 & 56.24 & 60.77 & 62.23 & $4.82^{\mathrm{NS}}$ \\
\hline CP from Afz : Nwb & - & $21.47^{\mathrm{b}}$ & $34.18^{\mathrm{a}}$ & 13.52 & 15.49 & $1.99^{* * *}$ \\
\hline $\mathrm{CP}$ from $\mathrm{PM}$ & $22.91^{\mathrm{a}}$ & $14.99^{c}$ & $14.27^{\mathrm{c}}$ & 18.95 & 15.92 & $1.39^{* * *}$ \\
\hline Total CP intake & $22.91^{\mathrm{c}}$ & $36.46^{\mathrm{b}}$ & $48.45 \mathrm{a}$ & 32.47 & 31.41 & $2.88^{* * *}$ \\
\hline Metabolic CP intake & $5.81^{\mathrm{c}}$ & $8.38^{\mathrm{b}}$ & $10.77^{\mathrm{a}}$ & 7.04 & 7.46 & $0.64^{* * *}$ \\
\hline NDF from Afz : Nwb & - & $38.81^{\mathrm{c}}$ & $61.80^{\mathrm{a}}$ & $46.88^{b c}$ & $53.58^{\mathrm{NS}}$ & $5.93^{* * *}$ \\
\hline NDF from PM & $191.45^{\mathrm{a}}$ & $125.30^{\mathrm{c}}$ & $119.16^{\mathrm{c}}$ & $158.31^{\mathrm{b}}$ & $133.01^{\mathrm{c}}$ & $11.57^{* * *}$ \\
\hline Total NDF intake & 191.45 & 164.10 & 180.96 & 205.19 & 186.59 & $15.18^{\mathrm{NS}}$ \\
\hline Metabolic NDF intake & 48.57 & 37.68 & 40.20 & 44.49 & 44.45 & $3.56^{\mathrm{NS}}$ \\
\hline ADF from Afz : Nwb & - & $30.90^{\mathrm{b}}$ & $49.20^{\mathrm{a}}$ & $27.63^{\mathrm{b}}$ & $31.64^{\mathrm{b}}$ & $3.68^{* * *}$ \\
\hline $\mathrm{ADF}$ from $\mathrm{PM}$ & $128.97^{\mathrm{a}}$ & $84.29^{c}$ & $80.27^{\mathrm{c}}$ & $102.03^{b}$ & $89.61^{\text {bc }}$ & $7.46^{* * *}$ \\
\hline Total ADF intake & 128.97 & 115.29 & 129.47 & 129.66 & 121.25 & $9.62^{\mathrm{NS}}$ \\
\hline Metabolic ADF intake ${ }^{\#}$ & 32.72 & 26.46 & 28.76 & 28.29 & 28.88 & $2.56^{\mathrm{NS}}$ \\
\hline Lignin from Afz : Nwb & - & $8.59^{b}$ & $13.68^{b}$ & $13.84^{\mathrm{a}}$ & $15.84^{\mathrm{a}}$ & $1.70^{* * * *}$ \\
\hline Lignin from PM & $27.07^{\mathrm{a}}$ & $17.71^{\mathrm{c}}$ & $16.85^{\mathrm{d}}$ & $22.38^{\mathrm{b}}$ & $18.81^{\mathrm{c}}$ & $1.64^{* * *}$ \\
\hline Total lignin intake & $27.07^{\mathrm{b}}$ & $26.30^{\mathrm{b}}$ & $30.53^{\mathrm{ab}}$ & $36.22^{\mathrm{a}}$ & $34.65^{\mathrm{a}}$ & $2.85^{*}$ \\
\hline Metabolic lignin intake $^{\#}$ & $6.87^{\mathrm{abc}}$ & $6.03^{c}$ & $6.78^{\mathrm{bc}}$ & $7.85^{\mathrm{ab}}$ & $8.23^{\mathrm{a}}$ & $0.61^{*}$ \\
\hline Cellulose from Afz : Nwb & - & $22.11^{\mathrm{b}}$ & $35.22^{\mathrm{a}}$ & $20.74^{\mathrm{b}}$ & $23.75^{\mathrm{b}}$ & $2.73^{* * * *}$ \\
\hline Cellulose from PM & $101.90^{\mathrm{a}}$ & $66.69^{c}$ & $63.42^{\mathrm{c}}$ & $84.26^{\mathrm{b}}$ & $70.30^{c}$ & $6.16^{* * *}$ \\
\hline Total cellulose intake & 101.90 & 88.80 & 98.64 & 105.01 & 94.55 & $7.74^{\mathrm{NS}}$ \\
\hline Metabolic cellulose intake ${ }^{\#}$ & 25.85 & 20.39 & 21.911 & 22.77 & 22.52 & $1.86^{\mathrm{NS}}$ \\
\hline Hemicellulose from Afz : Nwb & - & $8.11^{\mathrm{c}}$ & $12.92^{\mathrm{a}}$ & $9.61^{\mathrm{bc}}$ & $11.00^{\mathrm{ab}}$ & $1.22^{* * *}$ \\
\hline Hemicellulose from PM & $62.48^{\mathrm{a}}$ & $40.89^{c}$ & $38.89^{c}$ & $51.66^{\mathrm{b}}$ & $43.41^{\mathrm{c}}$ & $3.78^{* * * *}$ \\
\hline Total hemicelluloses intake & $62.48^{\mathrm{a}}$ & $49.99^{c}$ & $51.80^{\mathrm{bc}}$ & $61.27^{\mathrm{ab}}$ & $54.41^{\mathrm{abc}}$ & $4.46^{*}$ \\
\hline Metabolic hemicelluloses intake & $15.85^{\mathrm{a}}$ & $11.26^{\mathrm{b}}$ & $11.51^{\mathrm{b}}$ & $13.29^{\mathrm{b}}$ & $12.96^{\mathrm{b}}$ & $1.09^{* *}$ \\
\hline
\end{tabular}




\section{Nutrient intake and digestibility of West African dwarf goats}

A similar pattern to the intake of neutral detergent fibre was observed with acid detergent fibre (ADF) intake. The highest total ADF intake of $129.66 \mathrm{~g} /$ day was however from the $T_{D}$. Significant $(\mathrm{p}<0.05)$ difference between dietary treatment means was observed in the total intake of lignin. Recorded values ranged from $26.30 \mathrm{~g} /$ day $\mathrm{T}_{\mathrm{B}}$ to $36.22 \mathrm{~g}$.day $\mathrm{T}_{\mathrm{D}}$. The intake of hemicellulose followed a close pattern to that of lignin in this study. Cellulose intakes from Afzelia africana and Newbouldia laevis were highly $(\mathrm{p}<0.001)$ significant with the highest value in $\mathrm{T}_{\mathrm{C}}(35.22 \mathrm{~g} /$ day $)$ while that from Panicum maximum was in $\mathrm{T}_{\mathrm{A}}(101.90 \mathrm{~g} /$ day $)$. Generally, a similar trend was observed in terms of statistical differences with intake means for the different nutrients between the test diets.

The digestibility coefficient of nutrients in the basal diet of Panicum maximum supplemented with Afzelia africana and Newbouldia laevis fed to West African
Dwarf goats are shown in Table 3. Dry matter digestibility coefficients for the different test diets varied significantly $(\mathrm{p}<0.01)$. This was found to be least in $\mathrm{T}_{\mathrm{C}}(75.24 \%)$ and highest in $T_{E}(83.49 \%)$. Significant variations $(p<0.01)$ in the digestibility of organic matter was observed between the tested diets and ranged from $49.45 \%\left(\mathrm{~T}_{\mathrm{A}}\right)$ to $77.70 \%\left(\mathrm{~T}_{\mathrm{B}}\right)$. Differences in crude protein digestibility coefficients were not significant $(p>0.05)$ between the diets, though ranged from $57.87 \%$ in $\mathrm{T}_{\mathrm{D}}$ to $65.61 \%$ in $\mathrm{T}_{\mathrm{C}}$. Digestibility values obtained for neutral and acid detergent fibre varied significantly at $5 \%$ and $1 \%$ respectively between the treatment diets and were both highest in $\mathrm{T}_{\mathrm{D}}$. The digestibility coefficient values for lignin and cellulose were not significantly $(\mathrm{p}>0.05)$ different between the test diets. However, recorded coefficients for the digestibility of hemicelluloses differed significantly $(p<0.01)$ between the diets.

Table 3: Digestibility coefficients (\%) of nutrients in a basal diet ofPanicum maximum supplemented with Afzelia africana and Newbouldia laevis fed to West African d warf goats

\begin{tabular}{|c|c|c|c|c|c|c|}
\hline \multirow[b]{2}{*}{ Nutrient } & \multicolumn{5}{|c|}{ Treatment Diets } & \multirow[b]{2}{*}{ SEM \pm} \\
\hline & $\mathbf{T}_{\mathrm{A}}$ & $\mathbf{T}_{\mathbf{B}}$ & $\mathbf{T}_{\mathbf{C}}$ & $\mathbf{T}_{\mathrm{D}}$ & $\mathbf{T}_{\mathbf{E}}$ & \\
\hline Dry matter & $79.01^{\mathrm{bc}}$ & $76.83^{c}$ & $75.24^{\mathrm{c}}$ & $81.19^{\mathrm{ab}}$ & $83.49^{\mathrm{a}}$ & $1.92^{* *}$ \\
\hline Organic matter & $49.45^{\mathrm{c}}$ & $58.69^{\mathrm{bc}}$ & $50.57^{\mathrm{c}}$ & $77.70^{\mathrm{a}}$ & $72.41^{\mathrm{ab}}$ & $7.59^{* *}$ \\
\hline Crude protein & 60.98 & 64.07 & 65.61 & 57.87 & 60.54 & $10.44^{\mathrm{NS}}$ \\
\hline Nutrient detergent fibre & $38.53^{\mathrm{ab}}$ & $35.66^{\mathrm{b}}$ & $31.05^{\mathrm{b}}$ & $43.91^{\mathrm{ab}}$ & $55.71^{\mathrm{a}}$ & $8.07^{*}$ \\
\hline Acid detergent fibre & $32.12^{\mathrm{bc}}$ & $25.52^{\mathrm{c}}$ & $24.74^{\mathrm{c}}$ & $38.72^{\mathrm{b}}$ & $49.79^{\mathrm{a}}$ & $4.53^{* * *}$ \\
\hline Lignin & 26.55 & 21.24 & 25.45 & 26.86 & 37.17 & $8.08^{\mathrm{NS}}$ \\
\hline Cellulose & 64.34 & 60.61 & 75.73 & 83.06 & 80.64 & $8.71^{\mathrm{NS}}$ \\
\hline Hemicellulose & $55.17^{\mathrm{c}}$ & $83.29^{\mathrm{ab}}$ & $92.20^{\mathrm{a}}$ & $67.05^{\mathrm{bc}}$ & $80.95^{\mathrm{ab}}$ & $7.45^{* *}$ \\
\hline
\end{tabular}

\section{Discussion}

The variation observed in the dry matter content of the studied Panicum maximum and two test plant leaves might probably be due to their stages of growth and species difference, which were not however taken into consideration in this study. McDonald et al. (2011) reported that the different genetic potential of different plants allows them to respond to prevailing soil and climatic conditions differently. Crude protein content being the most important nutrient used to express the quality of plant is usually the most deficient component in animal diets. However, the values of crude protein obtained in this study were observed 


\section{Ikihimioya, Okoruwa and Ikhatua}

to be satisfactory for ruminant production and also exceed the minimum protein requirement of $6-8 \mathrm{~g} / 100 \mathrm{~g}$ for ruminants (Abdu et al., 2013). Ash content varied widely between Panicum and the test plant leaves. The implication of this finding therefore, is that the test plant leaves might be poor sources of essential mineral elements for ruminants. Hence this problem is likely to be alleviated, if they are used as supplements. The higher ether extract and nitrogen free extract obtained in Newbouldia laevis was an indication of good presence of essential oil and energy released to the goats compared with Panicum and Afzelia africana. The variation observed in crude fibre content and its fractions, offered explanation to the amount of fibre in Panicum and test plant leaves which provide to a large extent a measure of their indigestible portion in animals (Ukanwokwo and Ironkwe, 2013). On the average total daily dry matter intake was higher in Newbouldia laevis supplemented diets than in Afzelia africana (297.49 vs $269.94 \mathrm{~g} . \mathrm{d}^{-1}$ respectively). This higher intake is probably due to the fact that goats on Newbouldia laevis diets consumed more of the basal portion of the diets in order to meet their daily nutrient requirements. Besides, the higher total dry matter intake from the Newboulda laevis supplemented diets than the Afzelia africana supplemented diets could be a consequence of lower fill value of Newbouldia compared with Afzelia. The fact that dry matter intake in the Newbouldia supplemented diets decreased with increased inclusion could be suggestive of the presence of deleterious components that should require further studies. The proportion of dry matter ingested for the diets supplemented with Afzelia africana increased with increased inclusion thus suggesting its better acceptance as a supplement to Panicum maximum by the goats than Newbouldia laevis. This observation might have resulted from higher crude protein content in Afzelia compared with Newbouldia. This thinking is in line with the reports of Isah et al. (2015) that an increase in ad-libitum intake of diets occurs through an increase in its crude protein content. However, the total daily dry matter intake in this present study was lower than the maximum value of $416.40 \mathrm{~g} / \mathrm{day}$ reported by Anugwa et al. (2000). Goats on sole Panicum diet consumed 236.60g. $\mathrm{d}^{-1}$ organic matter but when supplemented with Afzelia and Newbouldia the organic matter intake decreased with increased inclusion. This observation could probably be as a result of poor sources of essential minerals from the test plant leaves. However, the total organic matter intake was higher in Newbouldia laevis supplemented diets than Afzelia africana. This could be a lower acceptance of Newbouldia by the goats and thus needed to consume more of the basal diet in order to meet organic matter requirements. The goats in this study offered the control diet (sole Panicum maximum) consumed a total crude protein of 22.91g.d-1 and when this was supplemented with Afzelia africana it increased to $36.46 \mathrm{~g} . \mathrm{d}^{-1}$ $\left(\mathrm{T}_{\mathrm{B}}\right)$ and $48.45 \mathrm{~g} \cdot \mathrm{d}^{-1}\left(\mathrm{~T}_{\mathrm{C}}\right)$. However, in this regard, the diets supplemented with Newbouldia laevis gave a reverse effect and did not differ. In terms of crude protein intake from the individual leaves in the trial diets, intake from $\mathrm{T}_{\mathrm{C}}$ recorded the highest value. This observation is likely due to the fact that Afzelia is a legume with naturally high protein content. Total crude protein values reported in this study were higher than the range of $8.6-30.4 \mathrm{~g} . \mathrm{d}^{-1}$ reported in goats study fed selected browse plants in combination with Panicum (Okah and Antia, 2016). The total neutral detergent fibre intake from the trial diets was highest in $T_{D}$ 


\section{Nutrient intake and digestibility of West African dwarf goats}

and as a whole in the Newbouldia laevis supplemented diets. This is mostly likely a reflection of the level of cell wall component in the diet mixtures. The total intake values for this fibre component in this study were higher than values reported for Albizia lebbeck as supplements (Adeloye, 2000). In contrast though, Hindrinchsen et al. (2001) reported much higher neutral detergent fibre intake values from multipurpose trees offered to sheep compared with the recorded values in this study. Acid detergent fibre, lignin, cellulose and hemicelluloses intake in this study showed quite similar trend across the dietary treatments as noted in neutral detergent fibre intake.

Digestibility values for dry matter in the treatment diets were generally high especially with Newbouldia laevis supplemented diets. The high solubility in the rumen of the crude protein in the test leaves might have contributed towards this effect. It is therefore likely that enough protein might have been available for microbial synthesis that increased fibre breakdown in the rumen. In other words, the proteins were more of the rumen degradable type, which might have aided fibre breakdown. Such proteins however are less efficiently utilized in the hindgut (Okoruwa and Okunola, 2017). These observed high values are consistent with the findings of Bamikole et al. (2003) involving Ficus religlesa as a supplement to Panicum maximum. Contrarily however, Okah et al. (2012) reported digestibility values (50.01 to $65.90 \%$ ) for sheep were higher than values obtained in this study. The high dry matter coefficients may probably had resulted from a lower intake of dry matter compared to other studies, hence maximum utilization by the animals. Organic matter digestibility varied widely between plants in this investigation.
Readily digestible fraction of organic matter in the test plant leaves was observed to be higher in Newbouldia laevis than Afzelia africana. This might be as a result of the organic matter content in the leaves, an indication of the possibility of a high amount of nutrient by-passing the rumen microbes. Compared to the reported crude protein digestibility coefficient range of between 48.69 and $61.98 \%$ (Abdu et al., 2013), this study reported higher values, which however did not have a definite pattern of difference between the treatment diets. Hence, the high crude protein content assumed present in the Afzelia africana supplemented diets did not seem to play any role in the digestibility of nutrient contrary to the report of Olafaden and Adebayo (2016).

The fibre fraction comprising neutral detergent fibre, acid detergent fibre, lignin, cellulose and hemicelluloses were poorly digested by goats in this study in contrast to the findings of Adeloye and Adeyina (2000) who reported higher values. Digestibility of these fibres was observed to be highest in diets supplemented with Newbouldia laevis with the exception of hemicelluloses. This observation might be explained by the assertion put forward by van Soest (1982) that increased protein intake is associated with high dry matter intake which in turn results in faster rates of passage of digesta through the gastro intestinal tract hence feed is exposed to digestive enzymes and rumen microbes for shorter periods resulting in low fibre digestibility.

\section{Conclusion}

The study showed that browse plants have higher potential over the mostly available and readily consumed Panicum maximum by small ruminants. The study indicated that feeding graded levels of Afzelia africana and Newbouldia laevis together with a basal diet of Panicum maximum promoted nutrient 


\section{Ikihimioya, Okoruwa and Ikhatua}

intake and enhanced digestibility in West African dwarf goats. The intake and digestibility of the dry matter in the trial plant leaves were found to be positively and highly influenced by the digestibility of organic matter and neutral detergent fibre respectively but not with crude protein. In conclusion, the combination of Panicum maximum based diet with Newbouldia laevis in a ratio of 50:50 happened to give the best results of nutrient digestibility. Hence, it is therefore recommended to small ruminant farmers in the diets of goats to enhance nutrient digestibility.

\section{References}

Abdu, S. B., Hassan, M. R., Adamu, H. Y., Yashim, S. M. and Oketona, G. F. 2013. Nutrient intake and digestibility of red sokoto bucks fed varying levels of Gmelina (Gmelina orborea) leaf meal. Nigerian Journal of Animal Science 15: 125-133.

Adeloye, A. A. 2000. Albizia lebbeck in nitrogen supplementation of sorghum glume :nutrient digestion and nitrogen utilization by goats. In: proceedings of the $7^{\text {th }}$ International Conference on Goats held $15-21^{\text {st }}$ May at Tours, France. Pp 84-85.

Adeloye, A. A. and Adeyinka, A. 2000. Supplementation of sorghum glume with Albizia lebbeck on nutrient intake, digestibility and rumen fermentation in goats. Tripical Animal Production Investigations 3(1): 11-18.

Anugwa, F. O. I., Okwori, A. I. and Ekwuno, P. O. 2000. Feed intake, nutrient digestibility and nutrient value of goats fed Panicum maximum and selected browse plants in southern guinea savannah zone of Nigeria. In: Proceeding of the $25^{\text {th }}$ Annual Conference of the
Nigeria Society for Animal Production, held at Umudike, 19 $23^{\text {rd }}$ March. Pp 63-66.

AOAC 1990. Association of Official Analytica Chemists. Official methods of analysis, $15^{\text {th }}$ ed., Washington, DC.

Bamikole, A., Babayemi, O. J., Arigbede, O. M. and Ikhatua, U. J. 2003. Nutritive value of Ficus religiasa in West African Dwarf goats. Animal Feed science and Technology 105: 71 -79 .

Duncan, D. B. 1955. Multiple range and multiple F - tests. Biometrics, 11: 1 42.

Fadiyimu, A. A., Fajemisin, A. N. and Alokan, J. A. 2011. Chemical composition of some selected browse plants and their acceptability by West African Dwarf sheep. Livestock Research for Rural Development, $\begin{array}{llll}2 & 3 & \left(\begin{array}{ll}1 & 2\end{array}\right) .\end{array}$ http://www.lrrd.org/rrd23/12/fadi233 56.htm

Goering, H. K. and Van Soest, P. J. 1970. Forage fibre analysis (apparatus, reagents, procedures and some applications). Agricultural Handbook No. 378. ARD - USDA. Washington, DC.

Gomez, K. A. and Gomez, A. A. 1984. Statistical procedures for Agricultural research $\left(2^{\text {nd }}\right.$ ed. In: John Wiley and sons, New York, USA. Pp $680-692$.

Hindrichsen, I. K., Osuyi, P. O., Odenyo, A. A., Madsen, J. and Hvelplund, T. 2001. Effects of supplementation with four multipurpose trees and lab purpureus on rumen microbial population, rumen fermentation, digesta, kinetic and microbial protein supply of sheep fed maize stover ad libitum. In: Proceedings of Tanzanian 
Society of Animal Production Science Conference, held $7-10^{\text {th }}$ August at Morogoro, Tanzania. Vol. $28 \mathrm{Pp} 14-17$.

Ikhimioya, I. and Imasuen, J. A. 2007. Blood profile of West African Dwarf goats fed Panicum maximum supplemented with Afzelia africana and Newbouldia laevis. Pakistan Journal of Nutrition 6910: 79-84.

Isah, O. A., Okunade, S. A., Aderinboye, R. Y. and Olafadehan, O. A. 2015. Effect of browse plant foliage supplementation on the performance of buckling goats fed threshed sorghum top basal diet. Tropical Animal Health and production 47(6): $1027-1032$.

McDonald, P., Edwards, R. A. Greehalgh, J. F. D., Morgan, C. A., Sinclair, L. A. and Wilkinson, R. G. (2011). Animal Nutrition. $7^{\text {th }}$ Edition. Pearson Prentice Hall

Okah, U. and Antia, E. A. 2016. Nutrient intake and digestibility of selected browse plants fed in combination with Panicum maximum to West African Dwarf (WAD) bucks. Nigerian Journal of Animal Production 43(2): 162-172.

Okah, U., Ibeawuchi, J. A. and Herbart, U. 2012. Nutrient intake and digestibility by West African Dwarf (WAD) sheep fed graded levels of boiled pigeon pea concentrate diets. Journal of Agricultural Technology 8(3): $837-849$.

Okoruwa, M. I. and Bamigboye, F. O. 2015. Performance characteristics of West African Dwarf goats fed sweet potato peels and cashew nut shell supplemented with Ocimum gratissium leaves. Journal of Advances in Life Science and Technology 35: 84-89.

Okoruwa, M. I. and Okunlola, D. O.
2017. Performance, carcass traits and meat quality evaluation of sheep fed diets containing napier grass and graded levels of cocoa pod husk with soursop pulp meals. Journal of Agricultural Studies 5(2): 74-85.

Okoruwa, M. I., Adewumi, M. K. and Ikhimioya, I. 2016. Performance characteristics and blood profile of rams fed mixtue of bamboo (Bambusa vulgaris) leaves and neem (Azadiratcha indica) seed cake. Nigerian Journal of Animal Production 43(2): 272-283.

Okunade, S. A., Olafadehan, O. A. and Isah, O.A. 2014. Fodder potential and acceptability of selected tree leaves by goats. Animal Nutrition and Feed Technology 14: 489-498.

Olafadehan, O. A. and Adebayo, O. F. 2016. Nutritional evaluation of ammoniated threshed sorghum top as a feed for growing goats. Tropical Health and Production 48940: 785 791.

Onyeonagu, C. C., Asiegbu, J. E., Nweke, A. R. and Akagha, C. S. 2011. Multipurpose uses of forages species, estimation of availability and distribution of rass species and effects of location on the crude fibre and ash contents of common browse species in Nsukka, Nigeria. Nigerian Journal of animal Production 38(1): 116- 124.

Ukanwokwo, A. I. and Ironkwe, M. 2013. Seasonal variation in the nutritive value of some browse fed of goats in Umudike, Southeastern Nigeia. Journal of Animal Science Advancement 3(1): 13-18.

van Soest, P. J. 1982. Nutritional Ecology of the Ruminant. Cornell University Press, Ithaca, New York, USA, Pp 373.

Received: $18^{\text {th }}$ May, 2017

Accepted: $24^{\text {th }}$ August, 2017 